\title{
Effect Momentum Evidence from Advance Emerging Markets
}

\author{
Błażej Podgórski*
}

\begin{abstract}
Objective - The momentum effect (Czekaj et al., 2014) is one of the most recognizable anomalies on the capital market. Based on the observed effect it is recommended to invest in shares that in the medium term (from 3 to 12 months) were characterized by the high growth of prices and it is worth selling discount securities. There are two hypotheses stated in the article: Momentum effect occurs on the analysed market, The momentum effect can be the basis for building a profitable investment strategy.

Research/methodology - Three methods verified the hypotheses: tests of differences, average and median rate of return, and dynamic models panelled with the estimation of parameters and generalized method of moments

Results - There is some evidence that the momentum effect exists on the Polish market, but it is the result of lower losses of winners' portfolio and is visible only for short-term investment horizons. The contrarian effect appears in the case of longer observations and investment horizons.

Originality/value - In the presented paper the author tries to examine that the anomaly that exists on the Warsaw Stock Exchange (WSE), one of the biggest emerging markets of the European Union. In a lot of research the WSE is classified as an advanced emerging market. The next important issue is the period of twenty years after the economic transformation in Poland. The last one is a wide range of research methods.
\end{abstract}

Keywords: effect momentum, advance emerging market, anomalies

\section{Introduction}

The momentum effect (Czekaj et al., 2014) is one of the most recognizable anomalies on the capital market. Based on the observed effect it is recommended to invest in shares that in the medium term (from 3 to 12 months) were characterized by the high growth of prices and it is worth selling discount securities. According to that assumption, the portfolio review should take place within 3 to 12 months.

The anomaly was discovered by Jegadeesh and Timan (1993) (JT), who built 32 different strategies that were combinations of the duration and investment period, as well as reaction time. Both periods of observation and investment were between one to four quarters. The division also included the time needed for investors to occupy positions and so 16 strategies involved an immediate response, and the other 16 were provided with a weekly delay. All of the analysed portfolios were characterized by positive return rates. The authors assumed that the portfolio which provides the most information and is the most representative

\footnotetext{
* Błażej Podgórski Ph.D., Koźmiński University, Department of Finance, Warsaw 03-301, 57 Jagiellońska street, e-mail: bpodgorski@alk.edu.pl.
} 
is the portfolio built on a period of six months of being observed and a six-month investment horizon with an immediate response. The result of the investment was an average annual return rate of $12.01 \%$, which was characterized by a statistical significance. Therefore, they put a special emphasis on its analysis, for example they divided the population into deciles, due to the size of the company and the monthly return rate. Moreover, for the strategy (6-6) they also analysed the dependence of the return risk on risk. The important conclusion is the fact that the return rate from the extreme deciles was comparable. Within the six-month portfolio and the six-month period of investment, they also analysed the division which covers the seasonal distribution of the return rates. What is important for further analysis was that the strategies launched in January were not effective.

\section{Literature review}

The analysis of the described anomaly were also conducted in developed European countries (Rouwenhorst, 1998b), in the G7 group (Bacmann, Dubois, Isakov, 2001), in 20 important stock markets on every continent (Chan et al., 2000) and in 18 stock markets of developed countries from North America, Europe, Asia and Australia (Du, 2008). All the mentioned scientists confirmed the existence of the anomaly.

Among the publications describing the existence of the momentum effect it is possible to find papers that refer to the strategy of the conceptions presented by behavioural finances. One of the first publications from that field is the study of Moskowitz and Grinblatt (1999) (MG). Except for the element of behavioural finances, the study implemented an analysis of the momentum effect considering the industry. Grimblatt and Han (2002) were examining the investors' rationality.

The effectiveness of investment strategies built on the basis of the momentum effect is also examined in the context of the economic situation. The phenomenon of large price increases which are independent from fundamental values is observed in the bull market periods. It is confirmed by the earlier cited result of a study that in the period of the dot-com bubble that even the information of the companies with similar names caused price changes in the prices of other companies. One of the first studies in this field was the previously mentioned analysis of Bacmann and others (2001). In the same direction follow the analysis of Cooper and others (2004), Grobys (2014), as well as Galasriotis et al. (2014). The study of Galasriotis extends the examined problem to explain the issue on the level of behavioural finance.

Two analyses of the momentum effect provided by Szyszka (2006) and Czekaj (2014) were conducted on the Polish market. The analyses took place in 2006 and they showed the effectiveness of the momentum strategy. Moreover, as the author of the study claims, the anomaly on the Polish market was stronger than in the mature markets. However, due to the immaturity of the Polish market and the lack of the possibility to conduct a short sale 
in the analysed period, the momentum effect was merely an illusory source of return, and thus the existing anomaly could not be corrected by the market participants. The study conducted in 2014 provides particularly relevant arguments in the discussion of the existence of the momentum effect. An analysis of the difference in cumulative return rates for the winning and losing stock portfolios indicates an increase in the effectiveness of the strategy from 1996 to 2006 and then their decline. The authors of the study in 2014, concluding their conclusions, state that the momentum effect on the Polish market does not provide any evidence that the hypothesis of information effectiveness is negative. However, this study leaves some insufficiency due to the fact that only simple statistical methods were used during the examination.

\section{Methodology and sample}

The analysis of the momentum effect was examining the portfolios' return rates of the win and lost shares. $10 \%$ shares of the highest return rates' companies were taken as the winners and $10 \%$ shares of the lost return rates' companies were taken as the lowest return rates. The study which followed the work of Jegadeesh and Titman (1993) was performed for various combinations of months observations and investments. The considered periods of the return rated' observation were one, three, six, nine and twelve months. Similarly the investment periods range from one to twelve months. According to this assumption the first hypothesis was formulated: Momentum effect occurs on the analysed market.

The presence of an anomaly does not provide the opportunity for its application in the terms of creating a profitable strategy thus the second hypothesis states: The momentum effect can be the basis for building a profitable investment strategy.

To verify those hypotheses, the author chose the Warsaw Stock Exchange - the biggest emerging market of the European Union, in a lot of research classified as the advance emerging market. In the research the author analyses 352 companies listed on the WSE from 1994 to 2013.

The study was conducted for the mean and median return rates obtained under each of the strategies. In the case of the mean analysis, the statistical significance was verified by the Satterthwaite-Welch t-test (Peng et al., 2011). The verification of statistical significance of median differences in turn was carried out by the Wilcoxon-Mann Whitney test (Martinez et al., 2012).

The existence of the momentum effect was also tested by using the dynamic panel models and GMM parameter estimation. The prepared models included at least one variable representing the return rate during the observation period of return. 


\section{Results}

The results will be presented in the following order: tests to vary the average return rates for stock portfolios of winners and losers shares (Tables 1 and 2), dynamic panel models for portfolios built according to the momentum strategies, with respectively 1.3.6 observation horizons, 9 and 12 months in Tables 3-7.

Table 1

Test for average return rate for the momentum strategy (\%)

\begin{tabular}{|c|c|c|c|c|c|c|c|c|c|c|c|}
\hline & & \multicolumn{10}{|c|}{ Investment period } \\
\hline & & \multicolumn{2}{|c|}{$1 \mathrm{~m}$} & \multicolumn{2}{|l|}{$3 \mathrm{~m}$} & \multicolumn{2}{|l|}{$6 \mathrm{~m}$} & \multicolumn{2}{|l|}{$9 \mathrm{~m}$} & \multicolumn{2}{|l|}{$12 \mathrm{~m}$} \\
\hline & \multicolumn{11}{|c|}{ Average return rates for winners portfolio } \\
\hline \multirow{17}{*}{ 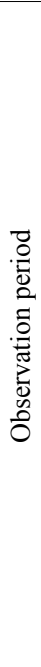 } & $1 \mathrm{~m}$ & -0.65 & $*$ & -0.38 & $* * *$ & -0.38 & $* * *$ & -1.81 & $* * *$ & -2.56 & $* * *$ \\
\hline & $3 \mathrm{~m}$ & 0.41 & $* * *$ & 1.14 & $* * *$ & 1.41 & $* * *$ & 1.48 & $* * *$ & 1.08 & $* * *$ \\
\hline & $6 \mathrm{~m}$ & 0.49 & $* * *$ & 1.55 & $* * *$ & 2.04 & $* * *$ & 1.89 & $* * *$ & 0.67 & $* * *$ \\
\hline & $9 \mathrm{~m}$ & 0.28 & $* * *$ & 1.55 & $* * *$ & 2.41 & $* * *$ & 1.93 & $* * *$ & 0.18 & $* * *$ \\
\hline & $12 \mathrm{~m}$ & 0.54 & $* * *$ & 1.52 & $* * *$ & 1.51 & $* * *$ & 0.69 & $* * *$ & -0.33 & $* * *$ \\
\hline & \multicolumn{11}{|c|}{ Average return rates for losers portfolio } \\
\hline & $1 \mathrm{~m}$ & -1.29 & $*$ & -3.90 & $* * *$ & -7.32 & $* * *$ & -10.28 & $* * *$ & -12.97 & $* * *$ \\
\hline & $3 \mathrm{~m}$ & -1.37 & $* * *$ & -4.89 & $* * *$ & -9.07 & $* * *$ & -11.09 & $* * *$ & -13.86 & $* * *$ \\
\hline & $6 \mathrm{~m}$ & -1.53 & $* * *$ & -4.88 & $* * *$ & -9.37 & $* * *$ & -12.75 & $* * *$ & -15.27 & $* * *$ \\
\hline & $9 \mathrm{~m}$ & -1.32 & $* * *$ & -4.48 & $* * *$ & -8.42 & $* * *$ & -11.03 & $* * *$ & -12.95 & $* * *$ \\
\hline & $12 \mathrm{~m}$ & -1.56 & $* * *$ & -4.17 & *** & -8.08 & $* * *$ & -10.54 & $* * *$ & -12.19 & $* * *$ \\
\hline & \multicolumn{11}{|c|}{ Subtract average return rates between theWinners and losers portfolio } \\
\hline & $1 \mathrm{~m}$ & 0.65 & $*$ & 3.52 & $* * *$ & 6.93 & $* * *$ & 8.47 & $* * *$ & 10.41 & $* * *$ \\
\hline & $3 \mathrm{~m}$ & 1.77 & $* * *$ & 6.04 & $* * *$ & 10.48 & $* * *$ & 12.57 & $* * *$ & 14.94 & $* * *$ \\
\hline & $6 \mathrm{~m}$ & 2.02 & $* * *$ & 6.43 & $* * *$ & 11.41 & $* * *$ & 14.65 & $* * *$ & 15.94 & $* * *$ \\
\hline & $9 \mathrm{~m}$ & 1.61 & $* * *$ & 6.03 & $* * *$ & 10.84 & $* * *$ & 12.96 & $* * *$ & 13.13 & $* * *$ \\
\hline & $12 \mathrm{~m}$ & 2.10 & $* * *$ & 5.68 & $* * *$ & 9.59 & $* * *$ & 11.23 & $* * *$ & 11.87 & $* * *$ \\
\hline
\end{tabular}

$* * *, * *, *$ - denote respectively 1,5 and 10 statistical significance levels for the Satterthwaite-Welch t-test.

Source: own calculation.

The results presented in Table 1 positively verify the momentum strategy of the average return rates on the Polish market in hypothesis 1 . In the short term, the charts maintain a previously observed trend, thus the anomaly occurs in the form of a continuation of the return rates. In each combination of the observation horizon and investment return rate obtained from the stock the winning stock were higher than the share of lost shares. The difference in return rates resulting from the implementation of Strategy 1-1 is statistically significant at the 10 level, while other strategies lead to statistically significant differences in return rates.

By analysing the returns of the winning portfolio, it is visible that the one month's observation horizon combined with all of the investment horizons does not generate any profit. This result is difficult to interpret. It may be clarified that one-month positive rates of return do not depend on the actual condition of the company. This would entail explaining the 
effect of momentum on the grounds of the classical finance school. In light of this, this effect is not a result of the continuation of the trend, but because of the long-term reforming conducted by the company's board.

Strategy 9-6 is the best combination for winning share portfolios in terms of return rates. The worst performance of the portfolio of losers is noted for the longest investment horizons: the losers from the 6-12 strategy generate a loss - over 15 per cent, which means that the companies are significantly losing their value.

\section{Table 2}

Tests for median return rates for the momentum strategy

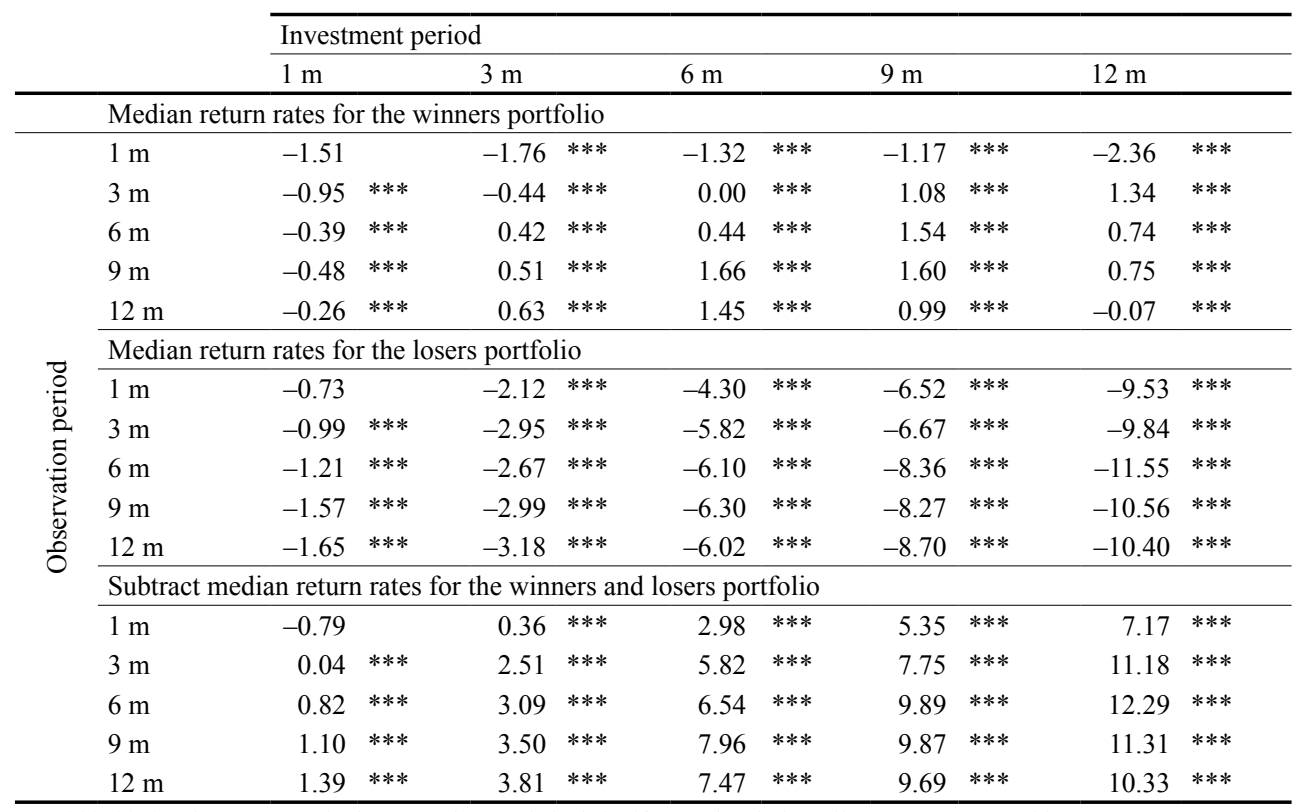

***, ${ }^{* *}, *-$ denote respectively 1,5 and 10 statistical significance levels for Wilcoxona-Manna-Whitney'a.

Source: own calculation.

The test results for the median return rates for the momentum strategy confirm to a large extent the conclusions of the tests for the mean. As for the tests of the averages, the strategy 1-1 for the winning company's portfolio does not give a positive return. The median return rates for the winning strategy portfolio with a one month horizon are negative. Also, all strategies with a one month investment horizon and strategies 3-3 and 12-12 generate losses for the purse.

The median return rates for both types of portfolios are significantly lower in absolute terms than the average return rates. The median difference for the stock portfolios of winners and losers in each strategy combination, other than strategy 1-1, is statistically significant. As in the case of tests for averages, the best in terms of monthly profitability is the 
strategy of 6-9 in the case of winning share portfolios. The median tests also confirm the earlier observation that the effectiveness of the strategy is the result of significant losses in lost purses.

To verify the stability of the previous momentum findings, according to the test pattern, its presence was checked by using the dynamic panel models. The estimation results for the individual investment horizons using the one-, three-, six-, nine- and twelve-month followup rates as the primary explanatory variables respectively (Tables 3-7).

Table 3

Dynamic panels models for the momentum strategy based on one month observation periods

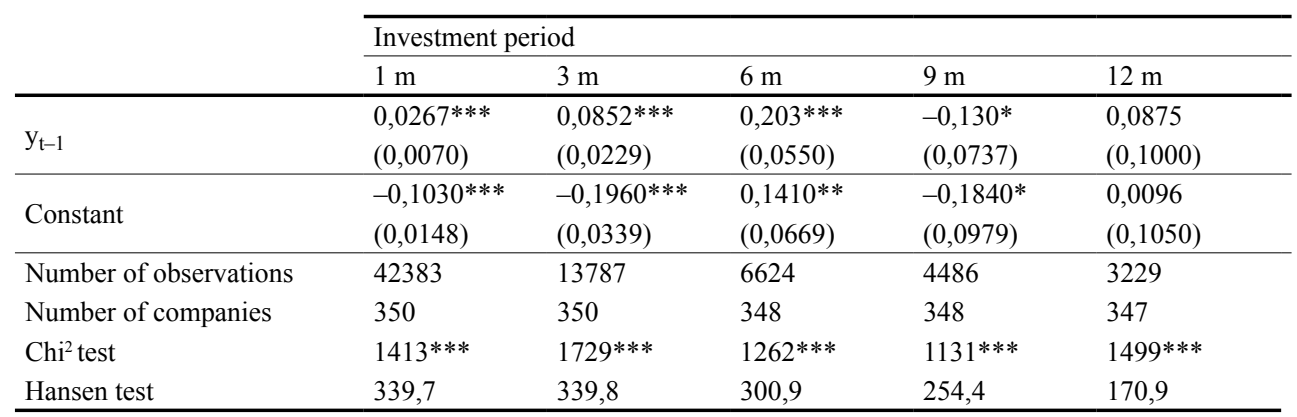

$\mathrm{y}_{\mathrm{t}-1}-$ denote return rate form observation period, standard mistakes are in brackets.

$* * *, * *, *$ - denote respectively 1,5 and 10 statistical significance.

Source: own calculation.

The tests conducted partly support the hypothesis 1 . Portfolios of the winning companies gave the higher returns than the stock portfolios of losers. The parameter for a variable delayed by one period, representing the observation period, in strategies 1-1, 1-3, 1-6 is positive and statistically significant at 1 . For strategies $1-9$, the delay variable is negative and statistically significant, but only at 10 and strategy $1-12$ is statistically insignificant. This demonstrates the effectiveness of strategies 1-1, 1-3 and 1-6.

The quality of the estimated models is supported by a large number of observations from over 40,000 strategies built in one month to nearly 3,300 strategies with a 12-month investment period. Each model is based on the shares of 350 entities. A test of cumulative static significance allows rejecting the hypothesis of the equality of the estimated parameters to zero at 1 . The Hansen test which verifies the selection of instruments also confirms to a reasonable point the model's properties. Similar features are available in the other models presented in subsection 1. Therefore, their econometric features will no longer be commented on.

In order to further verify the presence of an anomaly, it is necessary to analyse panel dynamic models for the remaining combinations of observation horizon and strategy investment. Secondary observation periods are analysed in the second order. These models are listed in Table 4. 


\section{Table 4}

Dynamic panels models for the momentum strategy based on three months observation periods

\begin{tabular}{|c|c|c|c|c|c|}
\hline & \multicolumn{5}{|c|}{ Investment period horizon } \\
\hline & $1 \mathrm{~m}$ & $3 \mathrm{~m}$ & $6 \mathrm{~m}$ & $9 \mathrm{~m}$ & $12 \mathrm{~m}$ \\
\hline $\mathrm{y}_{\mathrm{t}-1}$ & $\begin{array}{l}0,0101 \\
(0,0077)\end{array}$ & $\begin{array}{l}0,0003 \\
(0,0127)\end{array}$ & $\begin{array}{l}0,1040 * * * \\
(0,0270)\end{array}$ & $\begin{array}{l}-0,1310 * * * \\
(0,0388)\end{array}$ & $\begin{array}{l}0,0893 \\
(0,0584)\end{array}$ \\
\hline Constant & $\begin{array}{l}-0,0795^{* * *} \\
(0,0177)\end{array}$ & $\begin{array}{l}-0,2180 * * * \\
(0,0365)\end{array}$ & $\begin{array}{l}0,0514 \\
(0,0602)\end{array}$ & $\begin{array}{l}-0,1740 * \\
(0,0997)\end{array}$ & $\begin{array}{l}-0,1340 \\
(0,1160)\end{array}$ \\
\hline Number of observations & 13895 & 13546 & 6496 & 4405 & 3164 \\
\hline Number of companies & 350 & 350 & 348 & 348 & 344 \\
\hline $\mathrm{Chi}^{2}$ test & $1374 * * *$ & $1627 * * *$ & $1274 * * *$ & $1059 * * *$ & $1438 * * *$ \\
\hline Hansen test & 336,8 & 339,1 & 296,6 & $265,1^{*}$ & $176,5^{*}$ \\
\hline
\end{tabular}

$\mathrm{y}_{\mathrm{t}-1}-$ denote return rate form observation period, standard mistakes are in brackets.

$* * *, * *, *-$ denote respectively 1,5 and 10 statistical significance.

Source: own calculation.

The obtained results confirm only the effectiveness of the momentum strategy 3-6, the value of the $y_{t-1}$ variable is positive and statistically significant at the level of 1 . It is in favour of hypothesis 1 , which states that there is a momentum effect, but in the case of strategies 3-9 there is a contrarian effect, which is obviously incompatible with the discussed hypothesis. The parameter for a variable delayed by one period is in this case negative and statistically significant at the level of 1 .

The third group of dynamic panel models was prepared for strategies based on a 6 month observation period. The results of model estimation are presented in Table 5.

\section{Table 5}

Dynamic panel models for the momentum strategy based on six month observation periods

\begin{tabular}{|c|c|c|c|c|c|}
\hline & \multicolumn{5}{|c|}{ Investment period horizon } \\
\hline & $1 \mathrm{~m}$ & $3 \mathrm{~m}$ & $6 \mathrm{~m}$ & $9 \mathrm{~m}$ & $12 \mathrm{~m}$ \\
\hline \multirow{2}{*}{$\mathrm{y}_{\mathrm{t}-1}$} & $-0,0037$ & $-0,0083$ & 0,0191 & $-0,0741 * * *$ & 0,0488 \\
\hline & $(0,0080)$ & $(0,0118)$ & $(0,0163)$ & $(0,0270)$ & $(0,0353)$ \\
\hline \multirow{2}{*}{ Constant } & 0,0452 & $-0,0214$ & 0,0441 & $-0,2380 * *$ & $-0,1200$ \\
\hline & $(0,0340)$ & $(0,0323)$ & $(0,0791)$ & $(0,1160)$ & $(0,1210)$ \\
\hline Number of observations & 6706 & 6706 & 6360 & 4280 & 3094 \\
\hline Number of companies & 347 & 347 & 347 & 348 & 343 \\
\hline $\mathrm{Chi}^{2}$ test & $1095 * * *$ & $1507 * * *$ & $1199 * * *$ & $1030 * * *$ & $1409 * * *$ \\
\hline Hansen test & 293,0 & 297,8 & 294,1 & 255,4 & 171,4 \\
\hline
\end{tabular}

$\mathrm{y}_{\mathrm{t}-1}-$ denote return rate form observation period, standard mistakes are in brackets.

$* * *, * *, *$ - denote respectively 1,5 and 10 statistical significance.

Source: own calculation.

The results presented in Table 5 provide arguments that falsify the effectiveness of the momentum strategy on the Polish market. Hypothesis 1 is not confirmed for investment 
based on six-month observation periods. The only statistically significant result is for strategies 6-9, but it indicates a contrarian effect. The contrarian effect for a nine month investment horizon is contradicted by hypothesis 1 . However, it should be confirmed in the other two groups of models based on the nine and twelve-month observation periods shown in Tables 6 and 7, respectively.

\section{Table 6}

Dynamic panels models for the momentum strategy based on nine month observation periods

\begin{tabular}{llllll}
\multicolumn{7}{l}{} & \multicolumn{4}{l}{ Investment period } & & \\
\cline { 2 - 6 } & $1 \mathrm{~m}$ & $3 \mathrm{~m}$ & $6 \mathrm{~m}$ & $9 \mathrm{~m}$ & $12 \mathrm{~m}$ \\
\hline \multirow{2}{*}{$\mathrm{y}_{\mathrm{t}-1}$} & $-0,0119$ & $-0,0279^{* *}$ & $-0,0397^{* *}$ & $-0,0795^{* * *}$ & 0,0429 \\
& $(0,0115)$ & $(0,0139)$ & $(0,0171)$ & $(0,0214)$ & $(0,0283)$ \\
\hline \multirow{2}{*}{ Constant } & $-0,1600^{* * *}$ & $-0,2860^{* * *}$ & $-0,4850^{* * *}$ & $-0,3450^{* * *}$ & $-0,0270$ \\
& $(0,0442)$ & $(0,0634)$ & $(0,0653)$ & $(0,0699)$ & $(0,1180)$ \\
\hline Number of observations & 4517 & 4170 & 4170 & 4170 & 2988 \\
Number of companies & 348 & 346 & 346 & 346 & 339 \\
Chi ${ }^{2}$ test & $802,2 * * *$ & $953,8 * * *$ & $1018 * * *$ & $1065^{* * *}$ & $1378^{* * *}$ \\
Hansen test & 244,4 & 243,5 & 255,7 & $262,7 *$ & 168,0 \\
\hline
\end{tabular}

$\mathrm{y}_{\mathrm{t}-1}-$ denote return rate form observation period, standard mistakes are in brackets.

$* * *, * *, *$ - denote respectively 1,5 and 10 statistical significance.

Source: own calculation.

Hypothesis 1 is also not confirmed in models based on 9-month observation periods. The results show contrarian effects for portfolios 9-3, 9-6 and 9-9. The results for the other two types of portfolios are statistically insignificant. The values of parameters and their statistical significance are similar to those in strategies 6-9, although this time the Hansen test does not confirm a good choice of instruments. The new observation in

\section{Table 7}

Dynamic panels models for the momentum strategy based on twelve observation periods

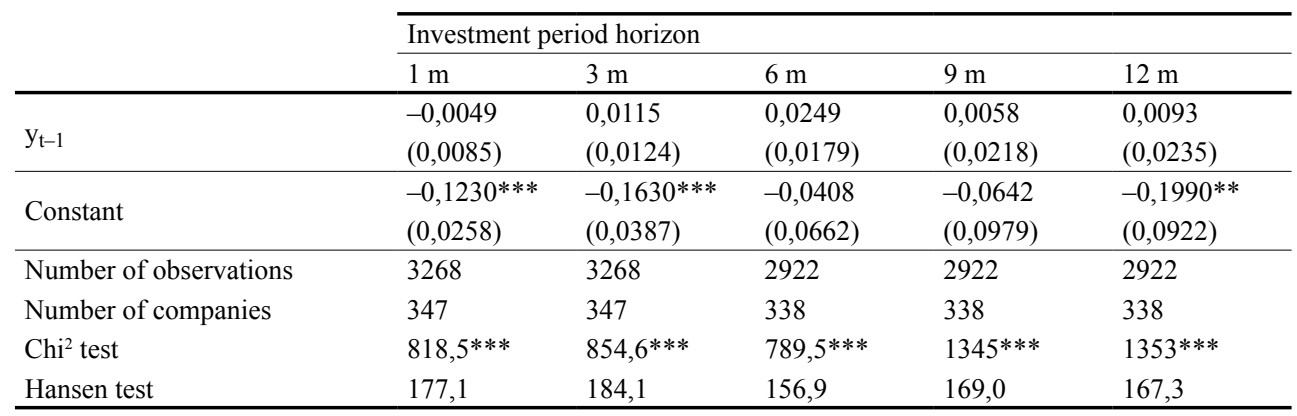

$\mathrm{y}_{\mathrm{t}-1}-$ denote return rate form observation period, standard mistakes are in brackets.

$* * *, * *, *$ - denote respectively 1,5 and 10 statistical significance.

Source: own calculation. 
comparison with the previously presented results is reversing the trend for 3 and 6 month investments. In both cases there is a contrarian effect and is statistically significant at 5 . The analysis of the momentum in Poland closes the analysis of portfolios built on the basis of the annual observation periods. Its results are presented in Table 7.

In models built for strategies based on twelve-month observation periods, the delayed return rates do not gain any statistical significance. They falsify hypothesis 1 which states that the momentum effect exists on a given market.

The results of the analysis of the momentum effect on the Polish market in the preliminary analyses indicated that the returns from the portfolio of winning shares were higher than those realized for the portfolio of losing shares during the investment period. This is largely the result of huge losses in the lost share portfolio. In addition, the analysis of dynamic panel models proves that the momentum effect occurs in the case of four strategies $1-1,1-3,1-6,3-6$. This is in part consistent with the results of the analysis of the average differences for which the six-month investment horizons generated the highest returns per month. An interesting result is the identification of, in the case of the analysis using dynamic panel models, the contrarian effect for nine months of investment and strategies 9-3 and 9-6. This is partly due to the analysis of the differences in average return rates for winning and losing portfolios in which cumulative return rates have been tested, and there has been a decline in yields for portfolios in the case of longer than six months of investment.

\section{Conclusion}

In conclusion, there is some evidence that the momentum effect exists on the Polish market, but it is the result of lower losses of winners portfolio and is visible only for short-term investment horizons. The contrarian effect appears in the case of longer observation and investment horizons. During analysing the results, it should be mentioned that the effectiveness of the momentum strategy on the Polish market was the result of large falls in the stock prices of losers, which means that the strategy could not be earned on the strategy. The results of the momentum analysis are sensitive to the used research method. In accordance with the results there are presumptions to reject hypothesis 1 and 2 .

\section{References}

Bacmann, J., Dubois, M., Isakov, D. (2001). Industries , business cycle and profitability of momentum strategies : An international perspective Industries, business cycle and profitability of momentum strategies: An international perspective. Social Science Research Network, January, 1-31.

Chan, K., Hameed, A., Tong, W. (2000). Profitability of Momentum Strategies in the International Equity Markets. The Journal of Financial and Quantitative Analysis, 2 (35). 153-172.

Cooper, M.J., Gutierrez, Jr. R.C., Hameed, A. (2004). Market States and Momentum. The Journal of Finance, 59 (3), $1345-1365$.

Czekaj, J. (2014). Efektywność giełdowego rynku akcji w Polsce z perspektywy dwudziestolecia. Warszawa: Polskie Wydawnictwo Ekonomiczne. 
Du, D. (2008). The 52-week high and momentum investing in international stock indexes. Quarterly Review of Economics and Finance, 48 (1). 61-77.

Galasriotis, E.C., Holmes, P., Kallinterakis, V., Ma, X.S. (2014). Market States, Expectations, Sentiment and Momentuw Naive are Investors? Journal Review of Financial Analysis, 32, 1-12.

Grinblatt, M., Han, B. (2002). The Disposition Effect and Momentum. National Bureau of Jegadeesh N. Lakonishok J. Chan L.K.C. (1996). Momentum Strategies. The Journal of Finance, 51 (5), 1681-1713.

Grobys, K. (2014). Momentum in global equity markets in times of troubles: Does the economic state matter? Economics Letters, 123 (1), 100-103.

Jegadeesh, N., Titman, S. (1993). Returns to Buying Winners and Selling Losers: Implications for Stock Market Efficiency. Journal of Finance, 48 (1), 65-91.

Jegadeesh, N., Titman, S. (2001). Profitability of Momentum Strategies: An Evaluation of Alternative Explanations. Journal of Finance, 56 (2), 699-720.

Moskowitz, T.J., Grinblatt, M. (1999). Do Industries Explain Momentum? Journal of Finance, 54 (4), $1249-1290$.

Rouwenhorst, K.G. (1998b). International Momentum Strategies. The Journal of Finance, 53 (1), $267-284$.

Szyszka, A. (2006). Zjawisko kontynuacji stóp zwrotu na Giełdzie Papierów Wartościowych w Warszawie. Bank i Kredyt. 8, 37-49.

Martínez-Murcia, F.J., Gorriz, J.M., Ramírez, J., Puntonet, C.G., Salas-González, D. (2012). Computer Aided Diagnosis tool for Alzheimer's Disease based on Mann-Whitney-Wilcoxon U-Test. Expert Systems with Applications, 39 (10), 9676-9685.

Peng, L., Tong, T. (2011). A note on a two sample T test with one variance unknown. Statistical Methodology, 8 (6), $528-534$.

Ahmed, T., Kullmann, O., Snevily, H. (2014). On the van der Waerden numbers. Discrete Applied Mathematics, $174,27-51$.

\section{EFEKT MOMENTUM. DOWÓD ZAAWANSOWANEGO RYNKU}

Streszczenie: $\mathrm{Cel}$ - Efekt momentum (Czekaj i in. 2014) jest jedną z najlepiej rozpoznanych anomalii na rynkach kapitałowych. Bazuje na inwestowaniu w spółki, które w ostatnim czasie (from 1 to 12 months) zyskiwały najwięcej i sprzedaży tych, które najwięcej traciły. Badaniu zostały podane dwie hipotezy. Efekt momentum występuje na analizowanym rynku. Efekt momentum może stanowić podstawę do budowy dochodowej strategii inwestycyjnej.

Metodologia badania - Do weryfikacji tych hipotez zostały wykorzystane trzy metody badawcze, różnice średnich i median stóp dochodu oraz dynamiczne modele panelowe.

Wynik - Efekt momentum występuje na polskim rynku, jednak jest to wynik mniejszych strat w portfelu spółek wygranych i jest widoczny tylko w krótkim terminie. Dla dłuższych okresów obserwacji i inwestycji widoczny jest efekt contarian.

Oryginalność/wartość - W prezentowanym artykule została przeprowadzona analiza występowania anomalii na Warszawskiej giełdzie, największym rynku rozwijającym się Unii Europejskiej. W wielu badaniach rynek ten jest klasyfikowany jako zaawansowany rynek rozwijający się. Kolejnym ważnym czynnikiem jest 20 letni okres po transformacji ekonomicznej. Ostatnim czynnikiem jest szeroki wachlarz metod analizy.

Słowa kluczowe: efekt momentum, zaawansowany rynek rozwijający się, anomalia

\section{Citation}

Podgórski, B. (2018). Effect Momentum Evidence from Advance Emerging Markets. Finanse, Rynki Finansowe, Ubezpieczenia, 2 (92), 325-334. DOI: 10.18276/frfu.2018.92-28. 